\title{
Anaplastic lymphoma kinase protein expression, genetic abnormalities, and phosphorylation in soft tissue tumors: Phosphorylation is associated with recurrent metastasis
}

\author{
YUKINAO ISHIBASHI ${ }^{1,2}$, HIROAKI MIYOSHI ${ }^{1}$, KOJI HIRAOKA ${ }^{2}$, FUMIKO ARAKAWA $^{1}$, \\ TOSHIAKI HARAGUCHI ${ }^{1,2}$, SHINJI NAKASHIMA ${ }^{1}$, TOSHIHIRO HASHIGUCHI ${ }^{1}$, TAKANORI SHODA ${ }^{2}$, \\ TETSUYA HAMADA ${ }^{2}$, TAKAHIRO OKAWA ${ }^{2}$, FUJIO HIGUCHI ${ }^{2}$, NAOTO SHIBA ${ }^{2}$, \\ KENSEI NAGATA $^{2}$ and KOICHI OHSHIMA ${ }^{1}$
}

Departments of ${ }^{1}$ Pathology and ${ }^{2}$ Orthopedic Surgery, School of Medicine, Kurume University, Kurume, Fukuoka 830-0011, Japan

Received October 30, 2014; Accepted December 22, 2014

DOI: $10.3892 / o r .2015 .3806$

\begin{abstract}
Gene and protein abnormalities of anaplastic lymphoma kinase (ALK) play an important role in the pathogenesis of various cancers and serve as important therapeutic targets. We investigated ALK protein expression, phosphorylation, and genetic aberrations using fluorescence in situ hybridization (FISH) in 81 soft tissue tumor samples: inflammatory myofibroblastic tumor, $\mathrm{n}=1$; alveolar soft part sarcoma, $\mathrm{n}=2$; leiomyosarcoma, $\mathrm{n}=10$; well-differentiated liposarcoma, $\mathrm{n}=7$; pleomorphic liposarcoma, $\mathrm{n}=2$; extraskeletal osteosarcoma, $\mathrm{n}=1$; epithelioid sarcoma, $\mathrm{n}=1$; synovial sarcoma, $\mathrm{n}=4$; malignant peripheral nerve sheath tumor, $n=4$; undifferentiated pleomorphic sarcoma, $n=19$; rhabdomyosarcoma, $n=6$; myxofibrosarcoma, $\mathrm{n}=8$; myxoid liposarcoma, $\mathrm{n}=11$; fibrosarcoma, $n=4$; and desmoid-type fibromatosis, $n=1$. ALK protein expression, gene signal gain (without translocation), and phosphorylation were observed in 33/81 (40.7\%), 55/81 (67.9\%), and 30/81 (37.0\%) tumor samples, respectively. ALK protein expression was statistically associated with phosphorylation, but not with gene signal gain. ALK phosphorylation-positive cases showed a statistically worse metastasis-free survival compared with phosphorylation-negative cases $(\mathrm{P}=0.0215)$. Particularly, metastasis of myxoid liposarcoma was associated with ALK phosphorylation $(\mathrm{P}=0.0019)$, but not with ALK protein expression or gene signal gain. However, the prognosis had no association with ALK protein expression, gene signal gain, or phosphorylation. ALK protein expression and phosphorylation play an important role in tumor biology
\end{abstract}

Correspondence to: Dr Hiroaki Miyoshi, Department of Pathology, School of Medicine, Kurume University, 67 Asahi-machi, Kurume, Fukuoka 830-0011, Japan

E-mail: miyoshi_hiroaki@med.kurume-u.ac.jp

Key words: anaplastic lymphoma kinase, soft tissue tumor, gene amplification, phosphorylation, metastasis and provide potential therapeutic targets for soft tissue tumors. Future research should focus on the oncogenic role and the efficacy of potential inhibitors of ALK.

\section{Introduction}

Anaplastic lymphoma kinase (ALK) is a receptor protein tyrosine kinase that possesses a single transmembrane domain and 1,620 amino acid residues $(1,2)$. Among normal tissues, ALK protein expression is prominent in the brain and peripheral nervous system of developing embryos and decreases rapidly after birth (3). In adults, the ALK protein is expressed at low levels and only in the central nervous system, while it has not been detected in other tissues (3). Thus, expression of this protein is considered to be a characteristic of abnormal cells.

Abnormalities in ALK at both the gene and protein levels play an important role in the pathogenesis of various cancers (4-13) and serve as important therapeutic targets (4). $A L K$ gene translocations and oncogenic fusion proteins have been reported in a variety of human malignancies, including anaplastic large cell lymphoma (ALCL) (13), non-small cell lung cancer (NSCLC) $(4,5)$, inflammatory myofibroblastic tumors (IMT) (6,7), and neuroblastomas (8-12). Other genetic alterations have also been detected, such as germ line or somatic mutations in neuroblastomas (8), gene insertions or amplifications in neuroblastomas and $\operatorname{NSCLC~}(5,8)$. In addition to IMT, rhabdomyosarcomas are another soft tissue tumors for which there have been several studies of ALK protein expression and gene amplification $(14,15)$. On the other hand, $A L K$ gene abnormalities and aberrant protein expression in other soft tissue tumors have not been well investigated.

Previously, Takeuchi et al improved the immunohistochemical sensitivity of the ALK protein through the development of the intercalated antibody-enhanced polymer (iAEP) method, which incorporates an intercalating antibody between the primary antibody and the dextran polymer-based detection reagents (16). In the case of lung cancer, sensitivity of the ALK protein using the iAEP method was higher than that using conventional procedures (16). ALK protein expression in 
soft tissue tumors has not been evaluated previously by means of the iAEP method.

ALK gene alterations and protein expression have the potential to activate the STAT3 $(17,18)$, AKT/PI3K (19), and RAS/ERK (20) pathways, which are involved in oncogenic processes, including cell proliferation, migration, and survival. Activation of those oncogenic pathways requires not only gene mutations or abnormal protein expression but also phosphorylation of ALK, which alters its function. Previous in vitro studies indicated an association among ALK phosphorylation, its oncogenic function, and poor prognosis (21). However, the mechanism by which ALK phosphorylation affects the clinical course of cancer patients has not been investigated previously.

The present study investigated ALK protein expression using the iAEP method, underlying $A L K$ genetic aberrations using fluorescence in situ hybridization (FISH), and ALK protein phosphorylation using immunohistochemical staining (IHS) in soft tissue tumors, as well as their relationship with the clinical course of cancer, such as prognosis and metastasis.

\section{Materials and methods}

Tissue samples. We retrieved 81 soft tissue tumor specimens from the Department of Orthopedic Surgery of Kurume University from 2001 to 2011. Paraffin-embedded tissues were used for diagnosis, histopathology, and IHS analyses. The antibodies used for immunostaining included those against CAM5.2 (BD Biosciences, San Jose, CA, USA), CD3, MyoD1, Bcl6 and CD34 (all from Leica Ltd., New Castle, UK), Bcl2 (Ventana Medical Systems, Inc., Tuscon, AZ, USA), vimentin, SMA, desmin, myogenin, S100, KP-1, AE1+AE3, EMA, CD20, and CD99 (all from Dako, Tokyo, Japan). All cases were diagnosed according to the World Health Organization (WHO) classification system (22). For IHS and FISH analyses, a tissue microarray was generated from 3-mm diameter cores derived from neoplastic lesions of each tumor case. Clinical information was obtained from patient medical charts. The use of clinical information and materials was approved by the Research Ethics Committee of Kurume University and was in accordance with the Declaration of Helsinki.

Immunohistochemical detection of the ALK protein using the iAEP method. We applied the iAEP method for immunohistochemical detection of ALK. The ALK Detection Kit (Nichirei Biosciences Inc., Tokyo, Japan) was used according to the manufacturer's protocol. Briefly, after deparaffinization, the slides were heated for $40 \mathrm{~min}$ at $95^{\circ} \mathrm{C}$ in antigen retrieval solution and subsequently incubated at room temperature with peroxidase blocking reagent for 5 min followed by incubation with the ALK antibody (clone, 5A4; dilution, 1:50) for $30 \mathrm{~min}$. The Bridge reagent and the Peroxidase-Labeled Empower reagent were applied for 15 and $30 \mathrm{~min}$, respectively, at room temperature. The immunohistochemical staining (IHS) results were categorized as either negative (-), weakly positive (1+), moderately positive (2+), or strongly positive (3+) (Fig. 1A). If a neoplastic cell was at least weakly positive, it was considered positive for ALK expression. We defined a tumor sample with $>30 \%$ positive neoplastic cells as a positive case.
Determination of ALK gene status by FISH analysis. FISH analysis was performed using an ALK (2p23) split-signal FISH DNA Probe (Dako) to detect chromosomal translocation of the $A L K$ gene and gene signal gain (copy no.) (Fig. 1B). If the split signal was detected in at least one out of 30 neoplastic cells, the tumor sample was defined as translocation-positive. If 3 or more gene copies per sample were detected in at least one out of 30 neoplastic cells, the tumor specimen was categorized as gene signal gain-positive.

Immunohistochemical analysis of phospho-Y1604 ALK expression. To evaluate phospho-Y1604 ALK expression, we performed immunostaining using the anti-ALK (phospho-Y1604) antibody (clone, EP661Y) (Abcam, Cambridge, UK). If a neoplastic cell was at least weakly positive (1+), it was considered positive for ALK expression, and any tumor specimen with $>30 \%$ positive cells was considered a positive case (Fig. 1C).

Immunohistochemical detection of the MIBI index. Sections $(4 \mu \mathrm{m})$ were deparaffinized in xylol and washed in distilled water, followed by treatment with an antibody against Ki-67 (clone M7240; Dako) in 0.001 M EDTA buffer, pH 8.0, for $20 \mathrm{~min}$ at $95-99^{\circ} \mathrm{C}$ in a microwave oven.

Using an optical microscope, Ki-67-positive cells were counted in 5 fields of a high power view randomly selected from each section. A case with $>10 \% \mathrm{Ki}-67$-positive cells was considered positive.

Statistical analysis. The Chi-square test and Fisher's exact test (two-sided test), which is appropriate for small values, were used to assess the associations among the IHS, FISH, and protein phosphorylation analyses. Event-free survival (EFS) was defined as the period from the time of histological diagnosis to that of detection of metastasis or the most recent follow-up evaluation. EFS and overall survival (OS) were determined using the Kaplan-Meier method, and the log-rank test was used to compare survival curves between the favorable and unfavorable risk groups. A P-value $<0.05$ in both Chi-square and Fisher's exact tests was indicative of statistical significance.

\section{Results}

Clinical characteristics. Table I presents the clinical information of all patients from whom the tumor samples used in this study originated. The 81 tissue samples were derived from 44 males and 37 females, who ranged in age from 2 to 88 years (mean 52.0 years). All patients underwent surgical resection. In addition to resection, 17 patients also received chemotherapy, 6 received radiation therapy, and 3 received chemoradiotherapy. Twenty-one of the subjects showed metastasis during the follow-up period, which ranged from 0 to 245 months (mean, 44.1 months).

Analysis of ALK protein expression, gene signal gain, and phosphorylation. Table II shows the characteristics and proportions of tumor cases that were positive for ALK protein expression, gene signal gain, and phosphorylation. The ALK protein was expressed in 33 samples (40.7\%), all of which 
A
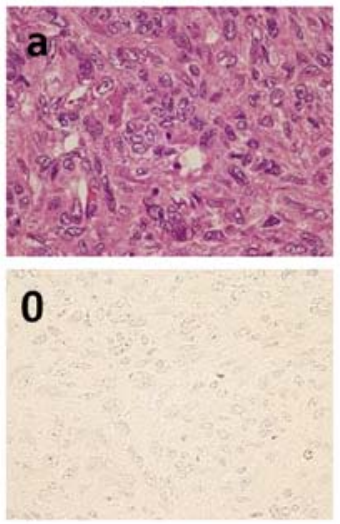
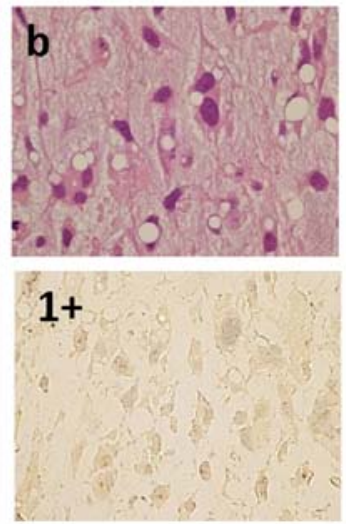
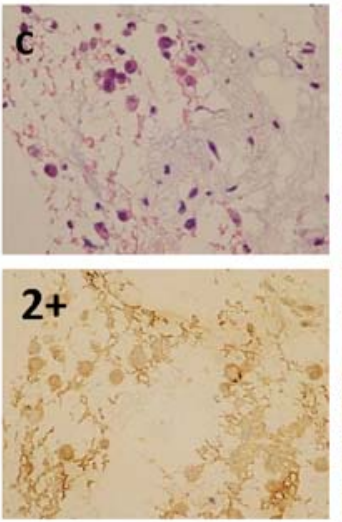
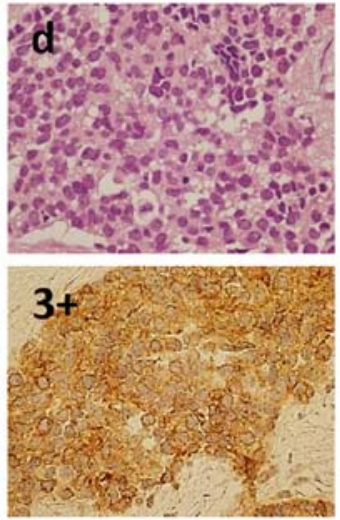

B
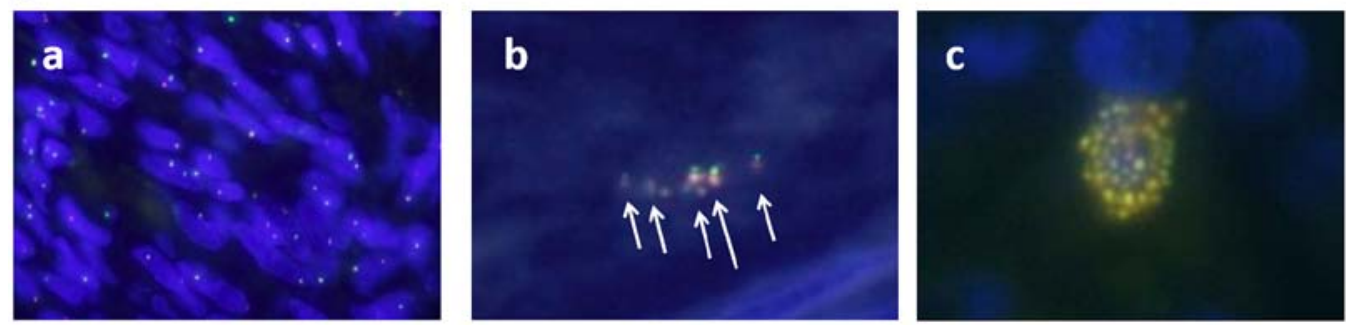

C
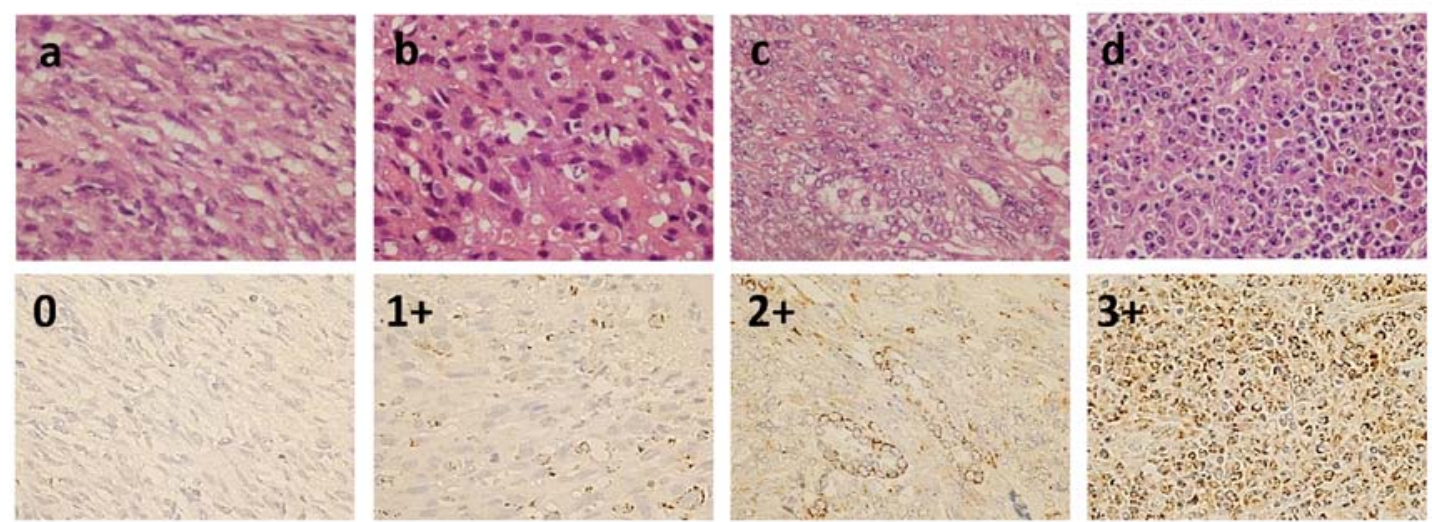

Figure 1. (A) Immunohistochemical staining of the ALK protein using the intercalated antibody-enhanced polymer (iAEP) method (original magnification $\mathrm{x} 400$ ). The intensity of protein staining was classified from 0 to 3+. (a) A malignant fibrous histiocytoma (MFH) sample that did not stain for ALK (score 0). (b) A myxoid liposarcoma sample that stained weakly (score 1+). (c) An epithelioid sarcoma sample that stained moderately (score 2+). (d) A rhabdomyosarcoma sample that stained strongly (score 3+). If a neoplastic cell was at least weakly positive, then it was defined as ALK protein-positive, and those tumor samples with more than $30 \%$ ALK protein-positive cells were defined as 'positive cases'. (B) FISH analysis of the $A L K$ gene. If at least one out of 30 neoplastic cells showed a split-signal, the tumor was defined as 'translocation positive' If at least one out of 30 neoplastic cells showed 3 or more non-split-signals (copies), the tumor was categorized as 'gene signal gain positive'. (a) A MFH sample with no gene translocation or gene signal gain. (b) A rhabdomyosarcoma sample with no translocation displaying $\sim 10$ non-split-signals (gene signal gain positive). (c) An inflammatory myofibroblastic tumor sample with no translocation displaying $\sim 30$ non-split-signals (gene signal gain positive). No translocation events of the $A L K$ gene were observed in the present study. (C) Immunohistochemical staining of phospho-Y1604 ALK (original magnification x400). The intensity of staining was classified from 0 to 3+. (a) A fibrosarcoma sample that did not stain (score 0). (b) A leiomyosarcoma sample that stained weakly (score 1+). (c) A synovial sarcoma sample that stained moderately (class 2+). (d) An inflammatory myofibroblastic tumor (IMT) sample that stained strongly (score 3+). If a neoplastic cell was at least weakly positive, the cell was considered positive for phospho-Y1604 ALK. The tumors with more than $30 \%$ positive cells were defined as 'positive cases'. ALK, anaplastic lymphoma kinase; FISH, fluorescence in situ hybridization; IHS, immunohistochemical staining.

showed tumor cells with diffusely stained cytoplasms but no nuclear staining (Fig. 1A). ALK gene translocation was not observed in any of the tumors, but $A L K$ gene signal gain was detected in 55 cases (67.9\%) (Fig. 1B). Thirty cases (37.0\%) were positive for phospho-Y1604 ALK expression, which had a diffuse membrane staining pattern (Fig. 1C). We were able to evaluate the MIB1 index in 67 of 81 cases, of which 39 samples (58.2\%) were positive.

Statistical association between ALK protein expression and phosphorylation. Table III indicates the statistical associations between protein expression and phosphorylation. Positive 
Table I. Clinical characteristics of the patients with soft tissue tumors.

\begin{tabular}{|c|c|c|c|c|c|c|c|c|c|c|c|}
\hline \multirow[b]{3}{*}{ Disease } & \multirow{3}{*}{$\begin{array}{l}\text { No. of } \\
\text { cases }\end{array}$} & \multirow{3}{*}{$\begin{array}{l}\text { Gender } \\
\overline{\mathrm{M} / \mathrm{F}}\end{array}$} & \multirow{2}{*}{\multicolumn{2}{|c|}{ Age (years) }} & \multicolumn{4}{|c|}{ Additional treatment } & \multirow{3}{*}{$\begin{array}{l}\text { No. of } \\
\text { metastatic } \\
\text { cases }\end{array}$} & \multirow{2}{*}{\multicolumn{2}{|c|}{$\begin{array}{l}\text { Follow-up } \\
\text { period } \\
\text { (months) }\end{array}$}} \\
\hline & & & & & Chemo- & & Chemo- & Resection & & & \\
\hline & & & Mean & Range & therapy & Radiation & radiotherapy & only & & Mean & Range \\
\hline All & 81 & $44 / 37$ & 52.0 & $2-88$ & 17 & 6 & 3 & 55 & $21 / 81$ & 44.1 & $0-245$ \\
\hline IMT & 1 & $1 / 0$ & 6.0 & 6 & 0 & 0 & 0 & 1 & $0 / 1$ & 16.0 & 16 \\
\hline $\begin{array}{l}\text { Alveolar soft } \\
\text { part sarcoma }\end{array}$ & 2 & $1 / 1$ & 32.0 & $14-50$ & 0 & 0 & 0 & 2 & $1 / 2$ & 85.5 & $65-106$ \\
\hline Leiomyosarcoma & 10 & $5 / 5$ & 61.7 & $49-87$ & 3 & 1 & 0 & 6 & $3 / 10$ & 26.6 & $5-60$ \\
\hline $\begin{array}{l}\text { Well-differentiated } \\
\text { liposarcoma }\end{array}$ & 7 & $4 / 3$ & 70.1 & $44-88$ & 0 & 0 & 0 & 7 & $0 / 7$ & 16.9 & $5-30$ \\
\hline $\begin{array}{l}\text { Pleomorphic } \\
\text { liposarcoma }\end{array}$ & 2 & $2 / 0$ & 62.0 & $61-63$ & 0 & 1 & 0 & 1 & $2 / 2$ & 56.0 & $51-61$ \\
\hline $\begin{array}{l}\text { Extraskeletal } \\
\text { osteosarcoma }\end{array}$ & 1 & $0 / 1$ & 80.0 & 80 & 0 & 0 & 0 & 1 & $1 / 1$ & 76.0 & 76 \\
\hline $\begin{array}{l}\text { Epithelioid } \\
\text { sarcoma }\end{array}$ & 1 & $0 / 1$ & 19.0 & 19 & 1 & 0 & 0 & 0 & $1 / 1$ & 5.0 & 5 \\
\hline $\begin{array}{l}\text { Synovial } \\
\text { sarcoma }\end{array}$ & 4 & $3 / 1$ & 35.5 & $23-57$ & 4 & 0 & 0 & 0 & $2 / 4$ & 24.8 & $11-40$ \\
\hline MPNST & 4 & $3 / 1$ & 25.1 & $14-43$ & 1 & 0 & 0 & 3 & $2 / 4$ & 36.7 & $13-127$ \\
\hline UPS & 19 & $11 / 8$ & 61.6 & $22-77$ & 2 & 3 & 0 & 14 & $5 / 19$ & 45.1 & $1-124$ \\
\hline $\begin{array}{l}\text { Rhabdo- } \\
\text { myosarcoma }\end{array}$ & 6 & $3 / 3$ & 16.2 & $2-57$ & 3 & 0 & 1 & 2 & $1 / 6$ & 36.2 & $0-108$ \\
\hline $\begin{array}{l}\text { Myxofibro- } \\
\text { sarcoma }\end{array}$ & 8 & $4 / 4$ & 67.3 & $39-83$ & 0 & 0 & 0 & 8 & $0 / 8$ & 47.6 & $24-81$ \\
\hline $\begin{array}{l}\text { Myxoid } \\
\text { liposarcoma }\end{array}$ & 11 & $5 / 6$ & 49.8 & $24-78$ & 2 & 0 & 2 & 7 & $2 / 11$ & 65.7 & $0-245$ \\
\hline Fibrosarcoma & 4 & $2 / 2$ & 46.0 & $24-71$ & 1 & 0 & 0 & 3 & $1 / 4$ & 71.5 & $27-120$ \\
\hline $\begin{array}{l}\text { Desmoid-type } \\
\text { fibromatosis }\end{array}$ & 1 & $0 / 1$ & 23.0 & 23 & 0 & 1 & 0 & 0 & $0 / 1$ & 10.0 & 10 \\
\hline
\end{tabular}

IMT, inflammatory myofibroblastic tumor; MPNST, malignant peripheral nerve sheath tumor; UPS, undifferentiated pleomorphic sarcoma; M, male; F, female.

phosphorylation rates were significantly higher in the ALK protein-expressing samples. The reverse relationship was also true, in that positive ALK protein expression rates were higher in the tumors that displayed ALK phosphorylation (Chi-square test, $\mathrm{P}=0.0003$; Fisher's exact test, $\mathrm{P}=0.0004)$. In the undifferentiated pleomorphic sarcoma (UPS and myxoid liposarcoma samples), the associations between ALK protein expression and phosphorylation were statistically significant by Chi-square test (UPS: $\mathrm{P}=0.0135$; myxoid liposarcoma: $\mathrm{P}=0.0325)$, but no significance was detected by the Fisher's exact test (UPS: $\mathrm{P}=0.0867$; myxoid liposarcoma: $\mathrm{P}=0.1818$ ).

Statistical associations among ALK gene signal gain, protein expression, phosphorylation, and the MIBI index. In all samples, positive ALK protein expression rates were not associated with positive signal gain rates (Chi-square test: $\mathrm{P}=0.8437$; Fisher's exact test: $\mathrm{P}=1.0000$ ) or phosphorylation rates (Chi-square test: $\mathrm{P}=0.1889$; Fisher's test: $\mathrm{P}=0.2261)$. In contrast, positive $A L K$ gene signal gain rates were in general positively associated with the MIB1 index (Chi-square test:
$\mathrm{P}<0.0001$; Fisher's test: $\mathrm{P}<0.0001)$ (Table IV). In the same analysis for leiomyosarcoma, well-differentiated liposarcoma, and UPS samples, the associations were statistically significant (Chi-square test: leiomyosarcoma, $\mathrm{P}=0.0027$; well-differentiated liposarcoma, $\mathrm{P}=0.0038$ and UPS, $\mathrm{P}=0.0004$; the Fisher's exact test: leiomyosarcoma, $\mathrm{P}=0.0357$; well-differentiated liposarcoma, $\mathrm{P}=0.0476$ and UPS, $\mathrm{P}=0.0037$ ).

Statistical association of the cancer clinical course with ALK protein expression and phosphorylation. Table V and Fig. 2 show the survival curves for EFS which are defined as the duration from the time of diagnosis to metastatic detection. The EFS curves were not statistically affected by ALK protein expression $(\mathrm{P}=0.8577)$.

However, statistically worse EFS was noted for the ALK phosphorylation-positive cases compared with the -negative cases, $(\mathrm{P}=0.0215)$. In addition, we also investigated this relationship for the sarcoma subtype, of which there were $>10$ cases. The phosphorylation of ALK was statistically associated with worse EFS in the myxoid liposarcoma cases $(\mathrm{P}=0.0019)$. 
A

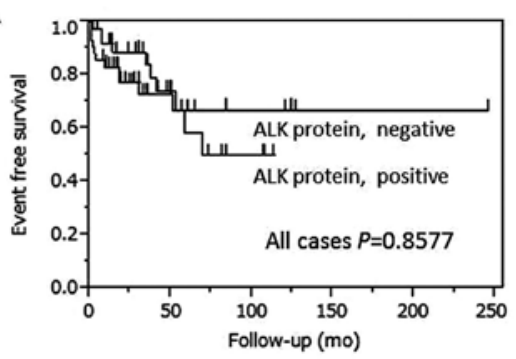

B

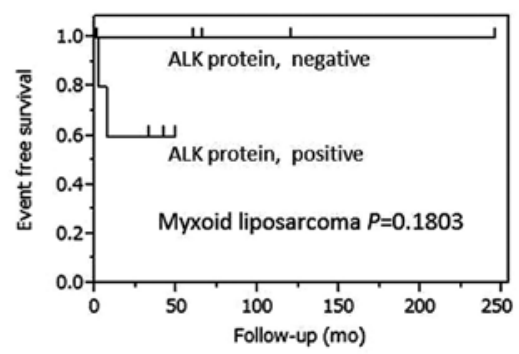

C

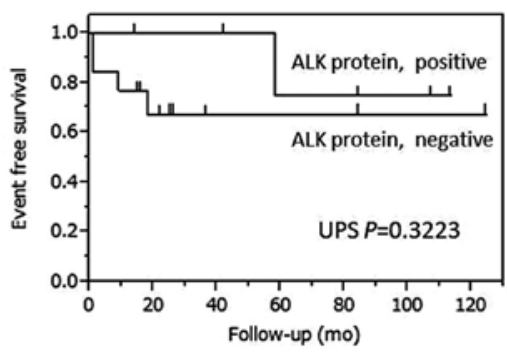

D

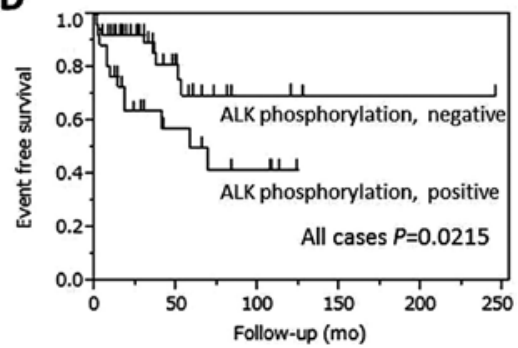

E

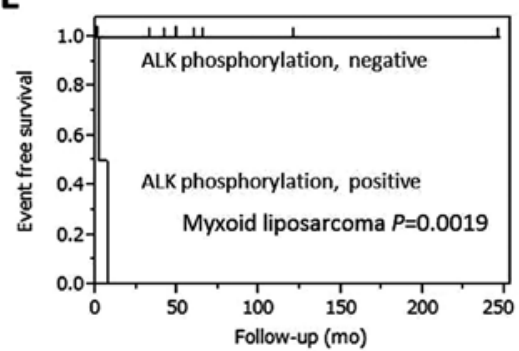

F

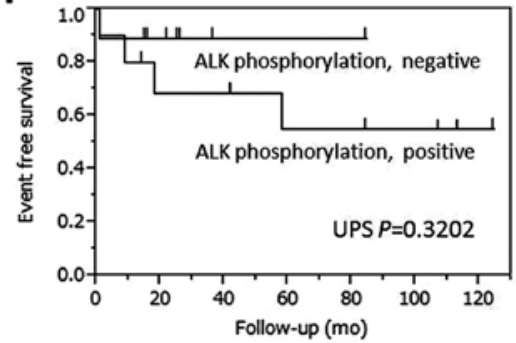

Figure 2. The statistical associations between the event-free survival (EFS) curves and ALK protein or phosphorylation (phospho-Y1604). The end point for the EFS analysis was the detection of metastasis. The relationship among protein expression, phosphorylation, and metastasis was analyzed in the sarcoma subtype, of which there were more than 10 cases. (A) The patients with tumors positive for ALK protein expression did not show significantly worse EFS compared with those with negative tumors ( $\mathrm{P}=0.8577)$. (B) EFS was not statistically different, respectively, in myxoid liposarcoma ( $\mathrm{P}=0.1803)$ and $(\mathrm{C}) \mathrm{UPS}$ $(\mathrm{P}=0.3223)$. (D) The patients with phosphorylation-positive tumors showed significantly worse EFS compared with those with phosphorylation-negative tumors $(\mathrm{P}=0.0215)$. (E) The phosphorylation status was statistically associated with EFS for the myxoid liposarcomas ( $\mathrm{P}=0.0019)(\mathrm{F})$. However, UPS only showed a tendency for association with metastasis, without statistical significance $(\mathrm{P}=0.3202)$. UPS, undifferentiated pleomorphic sarcoma; ALK, anaplastic lymphoma kinase.

Table II. Statuses of ALK protein expression, gene signal gain, phosphorylation, and the MIB1 ratio in soft tissue tumors.

\begin{tabular}{lcccc}
\hline Disease & $\begin{array}{c}\text { ALK protein expression (+) } \\
\text { n/total (\%) }\end{array}$ & $\begin{array}{c}A L K \text { gene signal gain }(+) \\
\text { n/total }(\%)\end{array}$ & $\begin{array}{c}\text { ALK protein phosphorylation }(+) \\
\text { n/total }(\%)\end{array}$ & $\begin{array}{c}\text { MIB1>10\% } \\
\text { n/total }(\%)\end{array}$ \\
\hline All & $33 / 81(40.7)$ & $55 / 81(67.9)$ & $30 / 81(37.0)$ & $39 / 67(58.2)$ \\
IMT & $1 / 1(100)$ & $1 / 1(100)$ & $1 / 1(100)$ & $1 / 1(100)$ \\
Alveolar soft part & $2 / 2(100)$ & $2 / 2(100)$ & $2 / 2(100)$ & $2 / 2(100)$ \\
sarcoma & & & & \\
Leiomyosarcoma & $0 / 10(0)$ & $7 / 10(70)$ & $2 / 10(20)$ & $6 / 8(75)$ \\
Well-differentiated & $4 / 7(57.1)$ & $2 / 7(28.6)$ & $2 / 7(28.6)$ & $2 / 7(28.6)$ \\
liposarcoma & & & & $1 / 2(50)$ \\
Pleomorphic & $2 / 2(100)$ & $1 / 2(50)$ & $2 / 2(100)$ & $1 / 1(100)$ \\
liposarcoma & & & & $1 / 1(100)$ \\
Extraskeletal & $0 / 1(0)$ & $1 / 1(100)$ & $1 / 1(100)$ & - \\
osteosarcoma & & & $2 / 4(50)$ & $1 / 3(33.3)$ \\
Epithelioid sarcoma & $1 / 1(100)$ & $1 / 1(100)$ & $1 / 4(25)$ & $1 / 2(50)$ \\
Synovial sarcoma & $3 / 4(75)$ & $3 / 4(75)$ & $10 / 19(52.6)$ & $10 / 15(66.7)$ \\
MPNST & $2 / 4(50)$ & $4 / 4(100)$ & $2 / 6(33.3)$ & $3 / 3(100)$ \\
UPS & $4 / 19(21.1)$ & $15 / 19(78.9)$ & $1 / 8(12.5)$ & $5 / 8(62.5)$ \\
Rhabdomyosarcoma & $3 / 6(50)$ & $5 / 6(83.3)$ & $3 / 11(27.3)$ & $3 / 11(27.3)$ \\
Myxofibrosarcoma & $5 / 8(62.5)$ & $5 / 8(62.5)$ & $0 / 4(0)$ & $3 / 3(100)$ \\
Myxoid liposarcoma & $6 / 11(54.5)$ & $4 / 11(36.4)$ & $0 / 1(0)$ & $0 / 1(0)$ \\
Fibrosarcoma & $0 / 4(0)$ & $3 / 4(75)$ & & \\
Desmoid-type & $0 / 1(0)$ & $1 / 1(100)$ & & \\
fibromatosis & & & & \\
\hline
\end{tabular}

ALK, anaplastic lymphoma kinase; IMT, inflammatory myofibroblastic tumor; MPNST, malignant peripheral nerve sheath tumor; UPS, undifferentiated pleomorphic sarcoma. 
Table III. Statistical association between ALK protein expression and phosphorylation.

\begin{tabular}{|c|c|c|c|c|c|c|}
\hline \multirow[b]{2}{*}{ Disease } & \multicolumn{2}{|c|}{ ALK protein (-) } & \multicolumn{2}{|c|}{ ALK protein $(+)$} & \multicolumn{2}{|c|}{$\mathrm{P}$-value } \\
\hline & $\begin{array}{c}\text { Phosphorylation (-) } \\
\text { n/total (\%) }\end{array}$ & $\begin{array}{c}\text { Phosphorylation }(+) \\
\text { n/total }(\%)\end{array}$ & $\begin{array}{c}\text { Phosphorylation (-) } \\
\text { n/total (\%) }\end{array}$ & $\begin{array}{c}\text { Phosphorylation }(+) \\
\text { n/total }(\%)\end{array}$ & $\begin{array}{l}\text { Chi-square } \\
\text { test }\end{array}$ & $\begin{array}{c}\text { Fisher's exact } \\
\text { test }\end{array}$ \\
\hline All & $38 / 48(79.2)$ & $10 / 48(20.8)$ & $13 / 33(39.4)$ & $20 / 33(60.6)$ & 0.0003 & 0.0004 \\
\hline IMT & $0 / 0$ & $0 / 0$ & $0 / 1(0)$ & $1 / 1(100)$ & - & - \\
\hline $\begin{array}{l}\text { Alveolar soft part } \\
\text { sarcoma }\end{array}$ & $0 / 0$ & $0 / 0$ & $0 / 2(0)$ & $2 / 2(100)$ & - & - \\
\hline Leiomyosarcoma & $8 / 10(80)$ & $2 / 10(20)$ & $0 / 0$ & $0 / 0$ & - & - \\
\hline $\begin{array}{l}\text { Well-differentiated } \\
\text { liposarcoma }\end{array}$ & $3 / 3(100)$ & $0 / 3(0)$ & $2 / 4(50)$ & $2 / 4(50)$ & 0.0925 & 0.4286 \\
\hline $\begin{array}{l}\text { Pleomorphic } \\
\text { liposarcoma }\end{array}$ & $0 / 0$ & $0 / 0$ & $0 / 2(0)$ & $2 / 2(100)$ & - & - \\
\hline $\begin{array}{l}\text { Extraskeletal } \\
\text { osteosarcoma }\end{array}$ & $0 / 1(0)$ & $1 / 1(100)$ & $0 / 0$ & $0 / 0$ & - & - \\
\hline Epithelioid sarcoma & $0 / 0$ & $0 / 0$ & $0 / 1(0)$ & $1 / 1(100)$ & - & - \\
\hline Synovial sarcoma & $1 / 1(100)$ & $0 / 1(0)$ & $1 / 3(33.3)$ & $2 / 3(66.7)$ & 0.1889 & 1.0000 \\
\hline MPNST & $2 / 2(100)$ & $0 / 2(0)$ & $1 / 2(50)$ & $1 / 2(50)$ & 0.1889 & 1.0000 \\
\hline UPS & $9 / 15(60)$ & $6 / 15(40)$ & 0/4 (0) & $4 / 4(100)$ & 0.0135 & 0.0867 \\
\hline Rhabdomyosarcoma & $2 / 3(66.7)$ & $1 / 3(33.3)$ & $2 / 3(66.7)$ & $1 / 3(33.3)$ & 1.0000 & 1.0000 \\
\hline Myxofibrosarcoma & $3 / 3(100)$ & $0 / 3(0)$ & $4 / 5(80)$ & $1 / 5(20)$ & 0.3115 & 1.0000 \\
\hline Myxoid liposarcoma & $5 / 5(100)$ & $0 / 5(0)$ & $3 / 6(50)$ & $3 / 6(50)$ & 0.0325 & 0.1818 \\
\hline Fibrosarcoma & $4 / 4(100)$ & 0/4 (0) & $0 / 0$ & $0 / 0$ & - & - \\
\hline $\begin{array}{l}\text { Desmoid-type } \\
\text { fibromatosis }\end{array}$ & $1 / 1(100)$ & $0 / 1(0)$ & $0 / 0$ & $0 / 0$ & - & - \\
\hline
\end{tabular}

ALK, anaplastic lymphoma kinase; IMT, inflammatory myofibroblastic tumor; MPNST, malignant peripheral nerve sheath tumor; UPS, undifferentiated pleomorphic sarcoma.

On the other hand, the OS curves were not statistically affected by either ALK protein expression or phosphorylation $(\mathrm{P}=0.5261$ and 0.8379 , respectively).

\section{Discussion}

Our findings revealed that almost $40 \%$ of the soft tissue tumor samples evaluated in the present study expressed the ALK protein and its phosphorylated form, according to iAEP and IHS, respectively, as well as $A L K$ gene signal gain, according to FISH. Statistically significant ratios were detected between ALK protein expression and phosphorylation (Chi-square test, $\mathrm{P}=0.0003$; Fisher's exact test: $\mathrm{P}=0.0004)$ and between gene signal gain and the MIB1 index (Chi-square test, $\mathrm{P}<0.0001$; Fisher's test, $\mathrm{P}<0.0001)$. The EFS was statistically worse for patients who were positive for ALK phosphorylation than for those who were negative, and this was also true for the subtype myxoid liposarcoma cases $(\mathrm{P}=0.0019)$.

Li et al (23) evaluated the ALK protein in alveolar soft part sarcomas (no. of positive cases/no. analyzed: $n=1$, proportion: $0 \%)$, well-differentiated liposarcomas $(n=19,47.4 \%)$, synovial sarcomas $(n=13,7.7 \%)$, malignant peripheral nerve sheath tumor (MPNST) $(n=12,8.3 \%)$, pleomorphic malignant fibrous histiocytoma (MFH) $(\mathrm{n}=27,22.2 \%)$, myxoid liposarcomas $(n=17,70.6 \%)$, and myxofibrosarcoma $(n=27,22.2 \%)$, among others. In comparison with those results, our study indicated equal or slightly higher rates of ALK protein expression in the following tumor types: alveolar soft part sarcomas $(n=2$, proportion: $100 \%)$, well-differentiated liposarcomas $(\mathrm{n}=7$, $57.1 \%)$, synovial sarcomas $(n=4,75 \%)$, MPNST $(n=4,75 \%)$, pleomorphic MFH $(\mathrm{n}=19,21.1 \%)$, myxoid liposarcomas $(\mathrm{n}=11$, $54.5 \%)$, and myxofibrosarcomas $(n=8,62.5 \%)$. A reason for the discrepancies could be attributed to our use of the iAEP method, which increased ALK detection sensitivity in comparison with traditional immunohistochemical methods. This method has been reported to be more efficacious for detecting the ALK protein in soft tissue tumors as well as in lung cancer (16).

Van Gaal et al (15), reported that $62.9 \%$ of rhabdomyosarcoma cases had an ALK copy no. gain, but without $A L K$ translocation, and this was positively correlated with ALK protein expression. In the present study, we also detected no ALK translocation but positive $A L K$ gene signal gain. Gene signal gain was not positively correlated with ALK protein expression but was positively correlated with the MIB1 index. $A L K$ gene signal gain seemed to have no association with $A L K$ specifically, but rather with mitosis and DNA polyploidy patterns.

ALK activation may cause cell proliferation depending on the position of phosphorylation within its intracellular 
Table IV. Statistical association between ALK gene signal gain and the MIB1 ratio.

\begin{tabular}{|c|c|c|c|c|c|c|}
\hline \multirow[b]{3}{*}{ Disease } & \multicolumn{2}{|c|}{ Gene signal gain (-) } & \multicolumn{2}{|c|}{ Gene signal gain $(+)$} & \multirow{2}{*}{\multicolumn{2}{|c|}{$\mathrm{P}$-value }} \\
\hline & \multirow{2}{*}{$\begin{array}{l}\text { MIB1 (-) } \\
\text { n/total (\%) }\end{array}$} & \multirow{2}{*}{$\begin{array}{l}\text { MIB1 (+) } \\
\text { n/total (\%) }\end{array}$} & \multirow{2}{*}{$\begin{array}{l}\text { MIB1 (-) } \\
\text { n/total (\%) }\end{array}$} & \multirow{2}{*}{$\begin{array}{l}\text { MIB1 (+) } \\
\text { n/total }(\%)\end{array}$} & & \\
\hline & & & & & Chi-square test & Fisher's exact test \\
\hline All & $18 / 23(78.3)$ & $5 / 23(21.7)$ & $10 / 44(22.7)$ & $34 / 44(77.3)$ & $<0.0001$ & $<0.0001$ \\
\hline IMT & $0 / 0$ & $0 / 0$ & $0 / 1(0)$ & $1 / 1(100)$ & - & - \\
\hline $\begin{array}{l}\text { Alveolar soft part } \\
\text { sarcoma }\end{array}$ & $0 / 0$ & $0 / 0$ & $0 / 2(0)$ & $2 / 2(100)$ & - & - \\
\hline Leiomyosarcoma & $2 / 2(100)$ & $0 / 2(0)$ & $0 / 6(0)$ & $6 / 6(100)$ & 0.0027 & 0.0357 \\
\hline $\begin{array}{l}\text { Well-differentiated } \\
\text { liposarcoma }\end{array}$ & $5 / 5(100)$ & $0 / 5(0)$ & $0 / 2(0)$ & $2 / 2(100)$ & 0.0038 & 0.0476 \\
\hline $\begin{array}{l}\text { Pleomorphic } \\
\text { liposarcoma }\end{array}$ & $0 / 1(0)$ & $1 / 1(100)$ & $1 / 1(100)$ & $0 / 1(0)$ & 0.0959 & 1.0000 \\
\hline $\begin{array}{l}\text { Extraskeletal } \\
\text { osteosarcoma }\end{array}$ & $0 / 0$ & $0 / 0$ & $0 / 1(0)$ & 1/1(100) & - & - \\
\hline Epithelioid sarcoma & - & - & - & - & - & - \\
\hline Synovial sarcoma & $0 / 0$ & $0 / 0$ & $2 / 3(66.7)$ & $1 / 3(33.3)$ & - & - \\
\hline MPNST & $0 / 0$ & $0 / 0$ & $1 / 2(50)$ & $1 / 2(50)$ & - & - \\
\hline UPS & $4 / 4(100)$ & $0 / 4(0)$ & $1 / 11(9.1)$ & 10/11 (90.9) & 0.0004 & 0.0037 \\
\hline Rhabdomyosarcoma & $0 / 0$ & $0 / 0$ & $0 / 3(0)$ & $3 / 3(100)$ & - & - \\
\hline Myxofibrosarcoma & $1 / 3(33.3)$ & $2 / 3(66.7)$ & $2 / 5(40)$ & $3 / 5(60)$ & 0.8499 & 1.0000 \\
\hline Myxoid liposarcoma & $6 / 7(85.7)$ & $1 / 7(14.3)$ & $2 / 4(50)$ & $2 / 4(50)$ & 0.2053 & 0.4909 \\
\hline Fibrosarcoma & $0 / 1(0)$ & $1 / 1(100)$ & $0 / 2(0)$ & $2 / 2(100)$ & - & - \\
\hline $\begin{array}{l}\text { Desmoid-type } \\
\text { fibromatosis }\end{array}$ & $0 / 0$ & $0 / 0$ & $1 / 1(100)$ & $0 / 1(0)$ & - & - \\
\hline
\end{tabular}

ALK, anaplastic lymphoma kinase; IMT, inflammatory myofibroblastic tumor; MPNST, malignant peripheral nerve sheath tumor; UPS, undifferentiated pleomorphic sarcoma.

Table V. P-values from the log-rank test comparing event-free survival (EFS) curves in soft tissue tumors.

\begin{tabular}{lcc}
\hline & \multicolumn{2}{c}{ EFS (metastasis) } \\
\cline { 2 - 3 } Disease & ALK protein (+) & Phosphorylation (+) \\
\hline All & 0.8577 & 0.0215 \\
Leiomyosarcoma & 0.2240 & 0.6495 \\
UPS & 0.3223 & 0.3202 \\
Myxoid liposarcoma & 0.1803 & 0.0019 \\
\hline
\end{tabular}

ALK, anaplastic lymphoma kinase; UPS, undifferentiated pleomorphic sarcoma.

domain (24-26). Phosphorylation of ALK is followed by activation of downstream signaling pathways, including PI3K/AKT, STAT3 and RAS/RAF/ERK, which trigger oncogenic changes (24). The anti-phospho-Y1604 antibody (clone, EP661Y), used in the clinical study, recognized the phosphorylated 1,604th tyrosine residue as the epitope (25). Wang et al reported that expression of phospho-Y1604 ALK was associated with oncogenic signaling (21). Other studies have shown that ALK inhibitors, including crizotinib, suppressed expression of phospho-Y1604 ALK (26). In a study on crizotinib therapy for lung cancer, 125 patients (94\%) with an ALK fusion event experienced tumor shrinkage (27). Our findings revealed that phospho-Y1604 ALK was expressed in almost $40 \%$ of the soft tissue tumor cases and is associated with poor clinical course. These results suggest that the expression of phospho-Y1604 ALK in soft tissue tumors is a potential therapeutic target of medication and, thus, can achieve more favorable prognoses. Further studies on the effect of ALK inhibitors on phosphoY1604 ALK expression are needed.

The suppression of metastasis by ALK inhibitors was reported in a mouse model, of pulmonary metastasis and survival, using an in vivo subcutaneous ALK positive xenograft mouse model (21). The present study showed a statistical association of phospho-Y1604 ALK expression with metastasis in soft tissue tumors and with ALK protein expression. These results potentially suggest that activation of ALK, indicated by its phosphorylation, is a more important factor in neoplastic cells than is its protein expression. ALK inhibitors may prevent progression of metastatic lesions in phospho-Y1604 ALK-positive tumors.

In conclusion, the iAEP method is considered to be more appropriate than other methods for detection of the ALK protein in soft tissue tumors. Aberrations of ALK protein expression and phosphorylation have been observed frequently 
in soft tissue tumors, and phosphorylation of ALK was associated with poor progression of metastasis. ALK plays an important role in tumor biology and provides potential therapeutic targets for soft tissue tumors. Future research is needed to explore the oncogenic function of ALK and the potential effect of ALK inhibitors.

\section{Acknowledgements}

The authors thank Mayumi Miura for her technical contribution.

\section{References}

1. Morris SW, Naeve C, Mathew P, et al: ALK, the chromosome 2 gene locus altered by the $t(2 ; 5)$ in non-Hodgkin's lymphoma, encodes a novel neural receptor tyrosine kinase that is highly related to leukocyte tyrosine kinase (LTK). Oncogene 14 2175-2188, 1997.

2. Iwahara T, Fujimoto J, Wen D, et al: Molecular characterization of ALK, a receptor tyrosine kinase expressed specifically in the nervous system. Oncogene 14: 439-449, 1997.

3. Pulford K, Lamant L, Morris SW, et al: Detection of anaplastic lymphoma kinase (ALK) and nucleolar protein nucleophosmin (NPM)-ALK proteins in normal and neoplastic cells with the monoclonal antibody ALK1. Blood 89: 1394-1404, 1997.

4. Zhang X, Zhang S, Yang X, et al: Fusion of EML4 and ALK is associated with development of lung adenocarcinomas lacking EGFR and KRAS mutations and is correlated with ALK expression. Mol Cancer 13: 188, 2010.

5. Salido M, Pijuan L, Martinez-Aviles L, et al: Increased ALK gene copy number and amplification are frequent in non-small cell lung cancer. J Thorac Oncol 6: 21-27, 2011.

6. Coffin CM, Hornick JL and Fletcher CD: Inflammatory myofibroblastic tumor: comparison of clinicopathologic, histologic, and immunohistochemical features including ALK expression in atypical and aggressive cases. Am J Surg Pathol 31: 509-520, 2007.

7. Cessna MH, Zhou H, Sanger WG, et al: Expression of ALK1 and p80 in inflammatory myofibroblastic tumor and its mesenchymal mimics: a study of 135 cases. Mod Pathol 15: 931-938, 2002.

8. De Brouwer BS, De Preter K, Kumps C, et al: Meta-analysis of neuroblastomas reveals a skewed ALK mutation spectrum in tumors with MYCN amplification. Clin Cancer Res 16: 4353-4362, 2010.

9. Chen Y, Takita J, Choi YL, et al: Oncogenic mutations of ALK kinase in neuroblastoma. Nature 455: 971-974, 2008.

10. George RE, Sanda T, Hanna M, et al: Activating mutations in ALK provide a therapeutic target in neuroblastoma. Nature 455: 975-978, 2008.

11. Mossé YP, Laudenslager M, Longo L, et al: Identification of ALK as a major familial neuroblastoma predisposition gene. Nature 455: 930-935, 2008.
12. Janoueix-Lerosey I, Lequin D, Brugieres L, et al: Somatic and germline activating mutations of the ALK kinase receptor in neuroblastoma. Nature 455: 967-970, 2008.

13. Morris SW, Kirstein MN, Valentine MB, et al: Fusion of a kinase gene, ALK, to a nucleolar protein gene, NPM, in non-Hodgkin's lymphoma. Science 263: 1281-1284, 1994.

14. Yoshida A, Shibata T, Wakai S, et al: Anaplastic lymphoma kinase status in rhabdomyosarcomas. Mod Pathol 26: 772-781, 2013.

15. van Gaal JC, Flucke UE, Roeffen MH, et al: Anaplastic lymphoma kinase aberrations in rhabdomyosarcoma: clinical and prognostic implications. J Clin Oncol 30: 308-315, 2012.

16. Takeuchi K, Choi YL, Togashi Y, et al: KIF5B-ALK, a novel fusion oncokinase identified by an immunohistochemistry-based diagnostic system for ALK-positive lung cancer. Clin Cancer Res 15: 3143-3149, 2009.

17. Kasprzycka M,Marzec M,Liu X, et al: Nucleophosmin/anaplastic lymphoma kinase (NPM/ALK) oncoprotein induces the T regulatory cell phenotype by activating STAT3. Proc Natl Acad Sci 103: 9964-9969, 2006.

18. Chiarle R, Simmons WJ, Cai H, et al: Stat3 is required for ALK-mediated lymphomagenesis and provides a possible therapeutic target. Nat Med 11: 623-629, 2005.

19. Bai RY, Ouyang T, Miething C, et al: Nucleophosmin-anaplastic lymphoma kinase associated with anaplastic large-cell lymphoma activates the phosphatidylinositol 3-kinase/Akt antiapoptotic signaling pathway. Blood 96: 4319-4327, 2000.

20. Zou HY, Li Q, Lee JH, et al: An orally available small-molecule inhibitor of c-Met, PF-2341066, exhibits cytoreductive antitumor efficacy through antiproliferative and antiangiogenic mechanisms. Cancer Res 67: 4408-4417, 2007.

21. Wang YW, Tu PH, Lin KT, et al: Identification of oncogenic point mutations and hyperphosphorylation of anaplastic lymphoma kinase in lung cancer. Neoplasia 13: 704-715, 2011.

22. Fletcher CDM, Bridge JA, Hogendoorn PCW and Mertens F: World Health Organization Classification of Tumours of Soft Tissue and Bone. IARC Press, Lyon, pp333-365, 2013.

23. Li XQ, Hisaoka M, Shi DR, et al: Expression of anaplastic lymphoma kinase in soft tissue tumors: an immunohistochemical and molecular study of 249 cases. Hum Pathol 35: 711-721, 2004.

24. Duijkers FA, Gaal J, Meijerink JP, et al: Anaplastic lymphoma kinase (ALK) inhibitor response in neuroblastoma is highly correlated with ALK mutation status, ALK mRNA and protein levels. Cell Oncol 34: 409-417, 2011.

25. Katayama R, Shaw AT, Khan TM, et al: Mechanisms of acquired crizotinib resistance in ALK-rearranged lung cancers. Sci Transl Med 4: 120ra17, 2012.

26. Palmer RH, Vernersson E, Grabbe $\mathrm{C}$ and Hallberg B: Anaplastic lymphoma kinase: signalling in development and disease. Biochem J 420: 345-361, 2009.

27. Camidge DR, Bang YJ, Kwak EL, et al: Activity and safety of crizotinib in patients with ALK-positive non-small-cell lung cancer: updated results from a phase 1 study. Lancet Oncol 13: 1011-1019, 2012. 